DOI: $\underline{10.17805 / g g z .2021 .1 .5}$

\title{
Линия жизни профессора Вячеслава Александровича Юркина. Сюжеты для творческого портрета
}

\author{
C. B. Коротеева \\ Московский гуманитарный университет
}

В статье исследована творческая биография профессора кафедры искусства Московского гуманитарного университета, заслуженного работника культуры Российской Федерачии Вячеслава Александровича Юркина. Он является известным специалистом по сценической речи и ораторскому мастерству. В актерской профессии важно научиться говорить на сцене так, чтобы зрители в самых дальних рядах происходящее на сцене слышали. Вячеслав Александрович окончил три вуза: музыкальный, педагогический и театральный. Он работал актером в театре, директором филармонии и театра. Многие годы он преподает. Ведет занятия на кафедре искусства Московского гуманитарного университета.

Ключевые слова: студенческая жизнь; работа в театре; театральная педагогика; сиеническая речь; ораторское искусство; В. А. Юркин

\section{The Life Line of Professor Vyacheslav Aleksandrovich Yurkin. Themes for a Creative Portrait}

\author{
S. V. Koroteeva \\ Moscow University for the Humanities
}

The article examines the creative biography of Vyacheslav Aleksandrovich Yurkin, Professor of the Department of Art at Moscow University for the Humanities, Honored Worker of Culture of the Russian Federation. He is a well-known expert on stage speech and public speaking. Being an actor, it is important to learn how to speak on stage so that the audience in the farthest rows can hear what is happening on stage. Vyacheslav Aleksandrovich graduated from three HEIs: musical, pedagogical and theatrical ones. He worked as an actor in theaters, director of the philharmonic hall and theater manager. He has been teaching for many years. The master conducts classes at the Department of Art, Moscow University for the Humanities.

Keywords: student life; work in the theater; theater pedagogy; stage speech; oratorical skills; V. A. Yurkin 


\section{ВВЕДЕНИЕ}

Жизнь каждого человека всегда с чего-то начинается... Вячеслав Александрович Юркин родился в 1946 г. Первое яркое впечатление у него осталось от похода его первого класса в Оренбургский драматический театр. Дети смотрели балетный спектакль «Тропою грома» о трагической любви цветного юноши и белой девушки по роману южноафриканского писателя Питера Генри Абрахамса. Балетный спектакль был посвящен расовым проблемам Южноафриканской республики, в которой между белыми и черными жителями существовали непреодолимые преграды. Первоклассник завороженно, не шелохнувшись, сидел на боковом балконе и зачарованно смотрел спектакль. Действие не только оставило яркое впечатление, но и определило его интерес к сцене и кино. Также очень сильное эмоциональное воздействие на детскую душу произвело первое посещение кинотеатра и просмотр фильма. Каждый поход в кино превращался в завораживающий праздник волшебного мира кинематографа.

\section{ПУТЬ В АКТЕРЫ}

Эти впечатления не прошли бесследно. Вячеслав Юркин в школе стал посещать драматический кружок. У него в то время было две страсти. Игра на сцене, которая в конечном итоге, привел его в Дворец культуры, где он был принят в самодеятельный Театр юного зрителя. Другое любимое занятие постоянные и систематические выезды на природу, охоту и рыбалку, за грибами. Эти выезды были частью семейного отдыха, за который отвечал отец.

Занятия в Театре юного зрителя Дворца культуры подготовили Вячеслава Юркина к поступлению в Саратовскую консерваторию на актерский факультет по специальности «Актер драматического театра и кино». Студенческая жизнь была насыщена различными встречами с артистами театра и кино. Однажды ему поручили сопроводить легендарную актрису Любовь Орлову на встречу со студентами актерского факультета. Встречи с известными деятелями искусства - это дополнительная программа обучения. Каждый из них что-то оставлял в душе и памяти. Были встречи с Мстиславом Ростроповичем, Павлом Массальским, Аллой Тарасовой и другими великими людьми нашего Отечества. Большой интерес вызвала встреча с советским эстрадным артистом Вольфом Мессингом, который использовал психологические приемы на своих выступлениях.

Вячеслав Александрович Юркин окончил с отличием актерский факультет Саратовской государственной консерватории имени Л. В. Собинова. После окончания обучения был приглашен на работу в Курский государственный драматический театр им. А. С. Пушкина. За время работы в театре удалось сыграть целый ряд интереснейших ролей: Керубино в «Женитьбе Фигаро», 
Павку Корчагина в «Драматической песне», Якова Свердлова в «Большевиках», Александра Пушкина в спектакле «Пушкин в Одессе». Это спектакль был рекомендован для просмотра школьникам города Курска. После этого по всем школам был объявлен городской конкурс на лучшее сочинение об Александре Сергеевиче Пушкине по мотивам просмотренного спектакля. За период работы в Курском драматическом театре В. А. Юркин прошел путь от артиста второй категории до артиста высшей категории.

Работая в театре, одновременно учился и окончил исторический факультет Курского государственного педагогического института, где впоследствии и стал преподавать ораторское искусство. Это был первый опыт педагогической деятельности.

\section{КРЫМСКАЯ ФИЛАРМОНИЯ}

В 1977 г. В. А. Юркин переехал в Крым и устроился на работу директором-распорядителем Крымского академического драматического театра им. М. Горького. За время его работы театр был удостоен звания «Академический», открыты дополнительные малые сценические площадки и посещаемость зрителями спектаклей достигла максимальной наполняемости зрительных залов.

В 1980 г. В. А. Юркин был назначен генеральным директором Крымской государственной филармонии. За 10-летний период его работы в этой должности филармония превратилась в крупнейшую концертную организацию Советского Союза, где ежедневно проводилось около 40 концертов в день по всем городам Крыма. В филармонии трудились более 360 штатных артистов.

Крымская филармония была организатором Международного фестиваля «Крымские зори». Силами ее сотрудников проводились международные конкурсы на лучшее исполнение песен стран социалистического содружества, а также целый ряд фестивалей различных жанров во всех городах Крыма. По инициативе В. А. Юркина была возрождена традиция проведения Чеховского фестиваля и приезда МХАТа в Ялту к А. П. Чехову. Был проведен I Всесоюзный конкурс балета, Фестиваль камерной музыки на базе Ливадийского и Воронцовского дворцов, Фестиваль симфонической музыки на набережной города Ялты. Крымская филармония обеспечивала проведение целого ряда мероприятий в городах-героях Керчи и Севастополе, Дней города Симферополя, Керчи, Феодосии, Севастополя, Евпатории, детского Международного фестиваля в городе Евпатории, Фестиваля камерной музыки в Никитском ботаническом саду и других культурно-массовых мероприятий (Киреева, 2019: Электронный ресурс).

Вячеслав Александрович Юркин, занимая должность генерального директора Крымской государственной филармонии, много времени уделял 
работе с артистами, создавал необходимые условия для творческого сотрудничества. В это период были присвоены почетные звания «Народный артист СССР» Юрию Богатикову и Софии Ротару. Звание «Народный артист Украины» получил художественный руководитель Симфонического оркестра Алексей Гуляницкий, звания заслуженных артистов Украины были присвоены ведущим артистам симфонического оркестра, солистам-инструменталистам, солистам-вокалистам. Впервые состав симфонического оркестра достиг максимальной численности в количестве 100 артистов. За период работы была проведена масштабная реконструкция ялтинского летнего концертного зала «Юбилейный».

Работая генеральным директором Крымской филармонии приглашал на гастроли в Крым и взаимодействовал с народными артистами СССР Иосифом Кобзоном, Людмилой Зыкиной, Махмудом Эсамбаевым, Владимиром Спиваковым, Юрием Гуляевым, Дмитрием Гнатюком, Евгенией Мирошниченко, Анатолием Соловьяненко, Марисом Лиепа, Аллой Пугачевой, с народными артистами России Львом Лещенко, Валентиной Толкуновой, Валерием Леонтьевым, Геннадием Хазановым и многими другими артистами (Киреева, 2019: Электронный ресурс).

В 1981 г. Вячеслав Александрович принимал участие в съемках художественного фильма «Душа» с Софией Ротару в главной роли, режиссером которого был Александр Стефанович. В период съемок состоялась встреча с народным артистом СССР Леонидом Утесовым.

После перевода Министерством культуры СССР в г. Москву был назначен административным руководителем Московского академического театра им. Вл. Маяковского, творческим руководителем которого являлся Герой Социалистического Труда, народный артист СССР, профессор А. А. Гончаров. В это время в театре служили выдающиеся мастера сцены А. Б. Джигарханян, Н. Г. Гундарева, А. С. Лазарев, С. В. Немоляева, И. М. Костолевский и др.

В 1985 г. Вячеслав Александрович Юркин окончил продюсерский факультет Государственного института театрального искусства им. А. В. Луначарского (ныне - ГИТИС) по специальности «Театровед-менеджер» (ГИТИС ..., б/д: Электронный ресурс).

\section{ДИРЕКТОР «ТАБАКЕРКИ»}

В 1990 г. В. А. Юркин был назначен директором Московского театрастудии под руководством О. Табакова. За период его работы театр встал в ряд лучших профессиональных театров Москвы, где труппа пополнилась такими именами как В. Л. Машков, Е. В. Миронов, С. В. Безруков, А. Ю. Заворотнюк и др. Были организованы и проведены гастроли театра в США, Японии, Канаде, Израиле, Италии, Австрии и других странах мира. В период работы в 
театре «Табакерка» за вклад в развитие культуры получил звание «Заслуженный работник культуры РФ» (Каминская, Попов, 2008: 128).

В 1991 г. В. А. Юркин преподавал в нескольких университетах США законы орфоэпии для американских студентов, изучающих русский язык, где в это время вместе с ним читал лекции и известный поэт Евгений Евтушенко.

В должности сопредседателя Крымского землячества в Москве проводит большую работу по популяризации Крыма и исторического события его возвращения в Россию (Юркин: «Россия сильна, когда ее народы едины», 2015: Электронный ресурс). По этим вопросам выступал на общегородских московских мероприятиях и митингах с участием известных политиков и руководителей различных фракций Государственной Думы РФ (Театральная площадь, Площадь Революции, Площадь у Белорусского вокзала, концертном зале «Крокус Сити Холл» и др.). По его инициативе были организованы и проведены в московских выставочных залах «Выхино» и «Бибирево» тематические выставки «Коктебель-Карадаг», на которых художниками Ассоциации «Акваживопись» Москвы и Крыма были представлены работы, посвященные уникальным крымским пейзажам. В 2014 г. была организована и открыта персональная художественная выставка члена Крымского землячества московской художницы Валентины Ивановны Щербаковой-Ионовой в помещении Госсовета Республики Крым.

По приглашению Общероссийского общественного движения «Россия», которое возглавлял видный политик и общественный деятель Геннадий Селезнев, и Национального фонда возрождения народных традиций от Крымского землячества принимал участие в патриотическом общественном проекте по возведению и посадке «Крымской аллеи» в Подмосковье на территории Национального конного парка «Русь». Посадка «Крымской аллеи», по замыслу авторов идеи, должна символизировать памятное событие в новейшей истории страны, связанное с возвращением Крыма в состав России. В данной акции совместно с ним принимали участие Геннадий Селезнев, Сергей Степашин, народные артисты России Александр Михайлов, Зинаида Кириенко, Юрий Назаров, Александр Панкратов-Черный (Крымское землячество, 2016: Электронный ресурс).

За значительный вклад в культурно-образовательное развитие Республики Крым, за активную гражданскую позицию в общественной деятельности крымского землячества В. А. Юркин был отмечен Благодарностью Главы Республики Крым С. В. Аксеновым.

В. А. Юркин принимал участие в качестве ведущего юбилейного концерта известного композитора, пианистки, народной артистки РСФСР Людмилы Лядовой в концертном зале «Крокус Сити Холл», посвященном ее 90летию. В период с 2016 г. по 2018 г. был председателем жюри Всероссийского 
конкурса чтецов «О Родине большой и малой», который проходил в культурном центре «Рублево» г. Москвы. С чтением стихов выступал на фестивале «Это было недавно, это было давно...» в концертном зале им. П. И. Чайковского.

\section{ЗАКЛЮЧЕНИЕ}

В 2015 г. В. А. Юркин был приглашен на работу в качестве профессора кафедры искусства Московского гуманитарного университета, где успешно преподает сценическую речь. Он принимает вступительные экзамены у абитуриентов, активно занимается научной и методической работой. За этот период им были опубликованы статьи в научных изданиях (Юркин, 2015, 2016, 2017, 2020; см. также: Школа ораторского искусства ... : Электронный ресурс).

\section{СПИСОК ЛИТЕРАТУРЫ}

ГИТИС — продюсерский факультет — выпускники - 1985 (б/д) [Электронный ресурс] // ГИТИС. URL: http://old.gitis.net/rus/faculty/producer/alumni/ 1985.shtml [архивировано в Wayback Machine] (дата обращения: 22.01.2021).

Каминская, Н., Попов, А. (2008) «Табакерка». История театрального подвала, или 30 лет спустя : [сборник очерков к юбилею театра]. М. : АСТ ; Астрель. 319 с.

Киреева, Е. (2019) На страже хорошего вкуса: история Крымской филармонии [Электронный ресурс] // Крымская газета. 1 апреля. URL: https://gazetacrimea.ru/news/na-straje-horoshego-vkysa-istoriya-krimskoi-filarmo nii-33046/ [архивировано в Wayback Machine] (дата обращения: 22.01.2021).

Крымское землячество (2016) [Электронный ресурс] // Постоянное Представительство Республики Крым при Президенте Российской Федерации. URL: http://www.ppcrimea.ru/index.php/ru/home/ob-edineniya-krymchan-v-mosk ve/krymskoe-zemlyachestvo [архивировано в Wayback Machine] (дата обращения: 22.01.2021).

Школа ораторского искусства Вячеслава Юркина [Электронный реcypc]. URL: http://master-slova.narod.ru/ [архивировано в Wayback Machine] (дата обращения: 22.01.2021).

Юркин, В. А. (2015) Режиссура поэтического театра. Спектакль и режиссер // Высшее образование для XXI века: XII Международная научная конференция, Москва, 3-5 декабря 2015 г. : доклады и материалы. Секция 5: Высшее культурологическое образование. Ч. 2 / отв. ред. А. В. Костина. М. : Изд-во Моск. гуманит. ун-та. С. 76-85.

Юркин, В. А. (2016) Проблемы режиссуры театра // Научные труды Московского гуманитарного университета. № 2. C. 21-30. DOI: 10.17805/trudy. $\underline{2016.2 .3}$ 
Юркин, В. А. (2017) Роль актера в публицистическом представлении // Высшее образование для XXI века: Проблемы воспитания. Москва, 14-16 декабря 2017 г. : доклады и материалы XIV Международной научной конференции : в 2 ч. / под общ. ред. И. М. Ильинского ; науч. ред. Ч. К. Ламажаа. М. : Изд-во Моск. гуманит. ун-та. Ч. 2. С. 207-208.

Юркин, В. А. (2020) Особенности сценической деятельности. Научнометодические материалы по специальности «актерское искусство» // Ученый совет. № 9. С. 67-73. DOI: 10.33920/nik-02-2009-07

Юркин: «Россия сильна, когда ее народы едины» (2015) [Электронный pecypc] // Взгляд. 23 октября. URL: https://vz.ru/news/2015/10/23/774052.html [архивировано в Wayback Machine] (дата обращения: 22.01.2021).

Дата поступления: 15.02.2021 2.

\section{REFERENCES}

GITIS - prodiuserskii fakul'tet - vypuskniki - 1985 [GITIS — Production Faculty — Alumni — 1985] (s.d.) GITIS [online] Available at: http://old.gitis.net/rus/faculty/producer/alumni/1985.shtml [archived in Wayback Machine] (accessed 22.01.2021). (In Russ.).

Kaminskaia, N. and Popov, A. (2008) «Tabakerka». Istoriia teatral'nogo podvala, ili 30 let spustia ["Tabakerka". The history of the theater basement, or 30 years later] : A collection of essays dedicated to the anniversary of the theater. Moscow : AST Publ. ; Astrel' Publ. 319 p. (In Russ.).

Kireeva, E. (2019) Na strazhe khoroshego vkusa: istoriia Krymskoi filarmonii [On guard for a true taste: The history of the Crimean Philharmonic]. Krymskaia gazeta, April 1. [online] Available at: https://gazetacrimea.ru/news/na-straje-horo shego-vkysa-istoriya-krimskoi-filarmonii-33046/ [archived in Wayback Machine] (accessed 22.01.2021). (In Russ.).

Krymskoe zemliachestvo [Crimean community]. (2016) Postoiannoe Predstavitel'stvo Respubliki Krym pri Prezidente Rossiiskoi Federatsii [online] Available at: http://www.ppcrimea.ru/index.php/ru/home/ob-edineniya-krymchan-v-moskve/ krymskoe-zemlyachestvo [archived in Wayback Machine] (accessed 22.01.2021). (In Russ.).

Shkola oratorskogo iskusstva Viacheslava Iurkina [Vyacheslav Yurkin School of Public Speaking]. [online] Available at: http://master-slova.narod.ru/ [archived in Wayback Machine] (accessed 22.01.2021). (In Russ.).

Yurkin, V. A. (2015) Rezhissura poeticheskogo teatra. Spektakl' i rezhisser [Directing in the poetic theater. Performance and director]. In: Vysshee obrazovanie dlia XXI veka [Higher education for the 21st century] : 12th International research conference, Moscow, December 3-5, 2015 : Reports and proceedings. Section 5: 
Higher cultural education. Part 2 / ed. by A. V. Kostina. Moscow : Moscow University for the Humanities Publ. Pp. 76-85. (In Russ.).

Yurkin, V. A. (2016) Problemy rezhissury teatra [Issues of stage directing]. Nauchnye trudy Moskovskogo gumanitarnogo universiteta, no. 2, pp. 21-30. (In Russ.). DOI: 10.17805/trudy.2016.2.3

Yurkin, V. A. (2017) Rol' aktera v publitsisticheskom predstavlenii [The role of actor in a socio-political performance]. In: Vysshee obrazovanie dlia XXI veka: Problemy vospitaniia [Higher education for the 21st century: Problems of personal development]. Moscow, December 14-16, 2017: Reports and proceedings of the 14th International research conference : in 2 pts. / ed. by I. M. Ilinskiy and Ch. K. Lamazhaa. Moscow : Moscow University for the Humanities Publ. Part 2. Pp. 207-208. (In Russ.).

Yurkin, V. A. (2020) Osobennosti stsenicheskoi deiatel'nosti. Nauchnometodicheskie materialy po spetsial'nosti «akterskoe iskusstvo» [The features of stage activity. Scientific and methodological materials for the acting majors]. Uchenyi sovet, no. 9, pp. 67-73. (In Russ.). DOI: 10.33920/nik-02-2009-07

Iurkin: «Rossiia sil'na, kogda ee narody ediny» [Yurkin: "Russia is strong when its peoples are united"]. (2015) Vzgliad, October 23. [online] Available at: https://vz.ru/news/2015/10/23/774052.html [archived in Wayback Machine] (accessed 22.01.2021). (In Russ.).

Submission date: 15.02.2021.

Коротеева Светлана Викторовна - доцент кафедры искусства Московского гуманитарного университета, художественный руководитель Детского театра песни «Светофор», лауреат международных конкурсов. Тел.: +7 (903) 761-07-15. Эл. адрес: svet.kor@mail.ru

KOROTEEVA, Svetlana Viktorovna, Associate Professor, Department of Art, Moscow University for the Humanities; Artistic Director, Children's Song Theater "Svetofor" ("Traffic Light"), winner of international contests. Tel.: +7 (903) 76107-15. E-mail: svet.kor@mail.ru

\section{Для циитирования:}

Коротеева С. В. Линия жизни профессора Вячеслава Александровича Юркина. Сюжеты для творческого портрета [Электронный ресурс] // Горизонты гуманитарного знания. 2021. № 1. C. 59-66. URL: https://journals.mosgu. ru/ggz/article/view/1369 (дата обращения: дд.мм.гггг). DOI: 10.17805/ggz.2021. $\underline{1.5}$ 